\title{
Sp1 Activation Cofactor Gene
}

National Cancer Institute

\section{Source}

National Cancer Institute. Sp1 Activation Cofactor Gene. NCI Thesaurus. Code C20686.

Sp1 Activation Cofactor Genes encode (at least 9) protein subunits of the CRSP (Cofactor Required for SP1 activation) complex, which, along with TFIID, is required for efficient activation of gene transcription by SP1, a transcription factor that recog nizes enhancer sites in target DNA. Many CRSP complex proteins are also components of other multisubunit complexes e.g. thyroid hormone receptor-(TR-) associated proteins that interact with TR and facilitate TR function on DNA templates in conjunction with initiation factors and cofactors. ( $\mathrm{NCl})$ 